\title{
Cellular growth and survival are mediated by $\beta 1$ integrins in normal human breast epithelium but not in breast carcinoma
}

\author{
Anthony R. Howlett ${ }^{1,4,{ }^{*},}$ Nina Bailey ${ }^{1}$, Caroline Damsky ${ }^{2}$, Ole W. Petersen ${ }^{1,3}$ and Mina J. Bissell ${ }^{1}$ \\ ${ }^{1}$ Life Sciences Division, Lawrence Berkeley Laboratory, University of California, Berkeley, CA \\ 94720, USA \\ ${ }^{2}$ Departments of Stomatology and Anatomy, University of California, San Francisco, CA 94143, \\ USA \\ ${ }^{3}$ Structural Cell Biology Unit, Department of Medical Anatomy A, The Panum Institute, \\ University of Copenhagen, DK-2200 \\ Copenhagen N, Denmark \\ ${ }^{4}$ Berlex BioSciences, Richmond, CA 94804, USA
}

*Author for correspondence at address 1

LBNL/DOE funding \& contract number: DE-AC02-05CH11231

\section{DISCLAIMER}

This document was prepared as an account of work sponsored by the United States Government. While this document is believed to contain correct information, neither the United States Government nor any agency thereof, nor The Regents of the University of California, nor any of their employees, makes any warranty, express or implied, or assumes any legal responsibility for the accuracy, completeness, or usefulness of any information, apparatus, product, or process disclosed, or represents that its use would not infringe privately owned rights. Reference herein to any specific commercial product, process, or service by its trade name, trademark, manufacturer, or otherwise, does not necessarily constitute or imply its endorsement, recommendation, or favoring by the United States Government or any agency thereof, or The Regents of the University of California. The views and opinions of authors expressed herein do not necessarily state or reflect those of the United States Government or any agency thereof or The Regents of the University of California. 


\section{Summary}

We previously established a rapid three-dimensional assay for discrimination of normal and malignant human breast epithelial cells using a laminin-rich reconstituted basement membrane. In this assay, normal epithelial cells differentiate into well-organized acinar structures whereas tumor cells fail to recapitulate this process and produce large, disordered colonies. The data suggest that breast acinar morphogenesis and differentiation is regulated by cell-extracellular matrix (ECM) interactions and that these interactions are altered in malignancy. Here, we investigated the role of ECM receptors (integrins) in these processes and report on the expression and function of potential laminin receptors in normal and tumorigenic breast epithelial cells. Immmunocytochemical analysis showed that normal and carcinoma cells in a three-dimensional substratum express profiles of integrins similar to normal and malignant breast tissues in situ. Normal cells express $\alpha 1, \alpha 2, \alpha 3, \alpha 6, \beta 1$ and $\beta 4$ integrin subunits, whereas breast carcinoma cells show variable losses, disordered expression, or downregulation of these subunits. Function-blocking experiments using inhibitory antiintegrin subunit antibodies showed a $>5$-fold inhibition of the formation of acinar structures by normal cells in the presence of either anti- $\beta 1$ or anti- $\alpha 3$ antibodies, whereas anti- $\alpha 2$ or $-\alpha 6$ had little or no effect. In experiments where collagen type I gels were used instead of basement membrane, acinar morphogenesis was blocked by anti- $\beta 1$ and $-\alpha 2$ antibodies but not by anti- $\alpha 3$. These data suggest a specificity of integrin utilization dependent on the ECM ligands encountered by the cell. The interruption of normal acinar morphogenesis by anti-integrin antibodies was associated with an inhibition of cell growth and induction of apoptosis. Function-blocking antibodies had no inhibitory effect on the rate of tumor cell growth, survival or capacity to form colonies. Thus under our culture conditions breast acinar formation is at least a two-step process involving $\beta 1$-integrin-dependent cellular growth followed by polarization of the cells into organized structures. The regulation of this pathway appears to be impaired or lost in the tumor cells, suggesting that tumor colony formation occurs by independent mechanisms and that loss of proper integrinmediated cell-ECM interaction may be critical to breast tumor formation.

\section{Key words}

mammary epithelium, extracellular matrix, basement membrane, integrin, growth, apoptosis 


\section{Introduction}

It is now widely accepted that extracellular matrix is a key component of tissue microenvironment and a determinant of functional differentiation in developing and adult epithelia (Stoker et al., 1990; Adams and Watt, 1993; Hay, 1993). In the mammary gland, extensive data exist showing that basement membrane components regulate the morphological and functional differentiation of mammary epithelial cells in culture and in vivo (Streuli et al., 1991; Petersen et al., 1992; Shearer et al., 1992; Sympson et al., 1994; for review see Howlett and Bissell, 1993). In addition, altered interactions with ECM have been observed in mammary tumor development, emphasizing the importance of microenvironmental regulation in normal development and malignancy (Chiquet-Ehrismann et al., 1986; for reviews see Haslam, 1991; Roskelley et al., 1993).

We recently established an assay for analyzing the mechanisms by which normal and malignant human mammary epithelial cells are regulated by microenvironmental cues in culture (Petersen et al., 1992). In this assay, when normal cells from twelve reduction mammoplasties and two normal cell lines were embedded in a reconstituted basement membrane as single cells, they underwent a process of morphogenesis to generate small, well-differentiated acinar structures that frequently deposited an endogenous basement membrane, secreted sialomucins apically, and stopped growing. In contrast, tumor cells from six established breast carcinoma cell lines and two breast carcinoma specimens failed to recapitulate this process and produced large, disorganized, poorly differentiated colonies and as far as the cell lines were concerned grew continuously. These data indicate the importance of cell-basement membrane interactions in the regulation of normal breast differentiation and point to a loss of this regulation in tumorigenesis. Since the two contrasting phenotypes expressed by normal and tumor cells are apparent only in the context of a physiologically relevant microenvironment (i.e. three-dimensional basement membrane) we hypothesized that correct cell-ECM interactions are suppressive for the expression of aberrant growth and differentiation characteristics. In other words, we proposed that as breast tumor cells manifest their malignant phenotype, they lose the capacity to respond correctly to information provided by the ECM.

Signals provided to mammary epithelium by basement membrane may be mediated by integrins, the transmembrane heterodimeric cell-surface receptors that link ECM to structural and functional elements within the cell (Hynes, 1992; Damsky and Werb, 1992; Juliano and Haskill, 1993). Evidence from the mouse mammary gland indicates that the expression of the mammaryspecific gene $\beta$-casein is triggered by signals from basement membrane, specifically conferred by elements of the laminin molecule (Streuli et al., 1991, 1995). The ECM signal is transduced through the $\beta 1$ integrin family, as evidenced by the ability of function-blocking anti- $\beta 1$ integrin antibodies to block the expression of $\beta$-casein (Streuli et al., 1991). With the advent of reliable criteria for discriminating normal and malignant human breast epithelial cells using basement membrane (Petersen et al., 1992), it is now possible to analyze the mechanisms of tumor cell responsiveness to basement membrane in relation to normal cells and the role of integrins in this process. Several integrin receptors for laminin are expressed in normal human mammary epithelium. These include $\alpha 1 \beta 1, \alpha 2 \beta 1, \alpha 3 \beta 1, \alpha 6 \beta 1$ and $\alpha 6 \beta 4$. Altered expression of these receptors is a common occurrence in breast tumors (Zutter et al., 1990; Koukoulis et al., 1991; D’Ardenne et al., 1991; Pignatelli et al., 1991, 1992; Jones et al., 1992; Natali et al., 1992; Zutter 
et al., 1993; Berdichevsky et al., 1994), implying that loss or downregulation of integrins may be critical to the development of malignancy by altering ECM-induced differentiation. It is not possible to conclude from surveys such as those mentioned above which of the many integrins expressed may be functionally active nor which change(s) in integrin expression may be of consequence in tumorigenesis.

We have used our reconstituted basement membrane assay to investigate the mechanisms of normal breast and breastcarcinoma cell interactions with basement membrane and have analyzed the expression and function of several integrins that recognize laminin. We report that: (1) normal cells and tumor cells express profiles of laminin-binding integrin receptor subunits that are similar, respectively, to those of normal and malignant breast tissue in situ; (2) cell survival, growth, and morphogenesis of acinar structures by normal cells is integrin dependent; and (3) the formation of disordered colonies by tumor cells occurs by pathways that are independent of those utilized for formation of acinar structures.

\section{Materials and Methods}

\section{Substrata and antibodies}

EHS matrix was prepared from EHS ascites tumors passaged in C57BL mice at a concentration of $7-10 \mathrm{mg} / \mathrm{ml}$ and stored at $0-4^{\circ} \mathrm{C}$ for up to 4 weeks as described (Streuli et al., 1991; Blaschke et al., 1994). In some experiments, commercially prepared EHS matrix (Matrigel, Collaborative Research, Bedford MA) was used. Type I collagen was extracted from rat tail tendons as described (Lee et al., 1984) and stored at $\sim 3 \mathrm{mg} / \mathrm{ml}$ in $0.1 \%$ acetic acid. The collagen solution was dialyzed 1 part collagen to 10 parts water with 3 changes over 48 hours at $4^{\circ} \mathrm{C}$ and equilibrated to $1 \times$ DME/F12 medium prior to use as described (Streuli et al., 1991).

Rabbit polyclonal antibodies to $\alpha 1$ (AB1934) and mouse monoclonal antibodies (mAbs) to $\alpha 2$ (clone P1E6 and clone CLB-150), $\alpha 3$ (clone P1B5), $\alpha 6$ (GoH3) and $\beta 1$ (clone JB1a) were obtained from Chemicon International, Temecula CA. Mouse mAbs against $\beta 4$ (clone 3E1) were obtained from Life Technologies, Gaithersberg MD. Rat mAbs to $\alpha 5$ (BII62; Werb et al., 1989), $\alpha 6$ (J1B5; Damsky et al., 1992) and $\beta 1$ (AIIB2; Damsky et al., 1992) were also used. Mouse monoclonal anti-human type IV collagen (PHM-12) (AMD, Armaton, Australia) was used to assess endogenous basement membrane immunoreactivity as described previously (Petersen et al., 1992).

\section{Cell culture}

Early passage HMT-3522 (Briand et al., 1987) and MCF-10A (Soule et al., 1990) breast epithelial cells, which behave like normal primary cells from reduction mammoplasties when cultured within EHS (Petersen et al., 1992), served as a model for normal breast epithelium. These cells form small polarized acinus-like structures within EHS that growth arrest by 6-12 days of culture. Tumorigenic HMT-3909/S13, MCF-7 subline 9, and MDA-MB-435 cells were used as a model for breast carcinoma. These cells form large disordered colonies that grow continuously when cultured within EHS (Petersen et al., 1992; Howlett et al., 1994). The normal and carcinoma cells were initially cultured in monolayer as previously described (Petersen et al., 
1992; Howlett et al., 1994). The carcinoma cells require type 1 collagen substrata for monolayer culture in serum-free medium (reviewed by Blaschke et al., 1995). The cells were then trypsinized and embedded in either $300 \mu \mathrm{l}$ of EHS matrix or a gel of collagen type I, as single cells, at a concentration of approximately $2.5 \times 105$ cells per well of a 24 -well plate and cultured as previously described (Petersen et al., 1992).

\section{Immunohistochemistry}

EHS cultures were fixed in either 2\% paraformaldehyde at ambient temperature for 20 minutes or in $1: 1$ methanol:acetone at $-20^{\circ} \mathrm{C}$ for $2-3$ minutes. Specimens were embedded in sucrose, frozen in Tissue-Tek OCT compound (Miles Laboratories), and $5 \mu \mathrm{m}$ frozen sections were prepared for immunostaining as described (Streuli et al., 1991). Sections were incubated with primary antibodies for 60 minutes followed by biotinylated secondary antibodies (30 minutes) and Texas Red-conjugated streptavidin (30 minutes). Control sections were stained with second antibodies only.

\section{Integrin function-blocking assays}

Antibodies against the $\alpha 2$ (clone P1E6), $\alpha 3$ (clone P1B5), $\alpha 5$ (clone BII62), $\alpha 6$ (GoH3), and $\beta 1$ (clone AIIB2) integrin subunits, and control non-immune mouse and rat IgG were introduced into the cellembedded substratum at the time of EHS and type I collagen gelation and into the medium at all subsequent medium changes at a range of concentrations from $10-100 \mu \mathrm{g} / \mathrm{ml}$. At the end of experiments, cultures were scored for the capacity of normal cells to produce mature acinar structures and the tumor cells to produce colonies. Ten random fields were viewed microscopically and the numbers of normal spheres or tumor colonies were counted in each field. The numbers of spheres/colonies formed in the presence of antibodies were calculated as a percentage of those formed by control cultures without antibodies.

\section{Analysis of cellular growth and apoptosis}

The growth capacity of cells was determined by 24-hour incorporation of $\left[{ }^{3} \mathrm{H}\right] \mathrm{TdR}(20 \mathrm{Ci} / \mathrm{mmol}$, NEN Research Products, Dupont) and determination of thymidine-labeling indices in $5 \mu \mathrm{m}$ frozen sections as described (Petersen et al., 1992).

Apoptosis was assessed in frozen sections by detection of FITCdigoxigenin nucleotide labelling of 3'OH DNA ends using the ApopTag in situ apoptosis detection kit (Oncor, Gaithersberg, MD). Thymocytes isolated from human peripheral blood were used as controls. Nuclei were counterstained with DAPI as described (Streuli et al., 1991).

\section{Experimental subjects}

In conducting research using animals, the investigators adhered to the 'Guide for the Care and Use of Laboratory Animals', prepared by the Committee on Care and Use of Laboratory Animals of the Institute of Laboratory Animal Resources, National Research Council (NIH 
publication no. 86-23, revised 1985). In the conduct of research where humans were the subjects, the investigators adhered to the policies regarding the protection of human subjects as prescribed by 32 CFR 219 and subparts B, C and D.

\section{Results}

\section{The profile of integrin subunits expressed by normal and tumorigenic human breast epithelial cells in vivo is recapitulated in three-dimensional culture}

To determine whether normal and tumor cells, cultured within reconstituted basement membrane, express a profile of integrins similar to that shown in vivo, normal HMT-3522 cells and tumorigenic HMT-3909/S13, MCF-7 subline 9 (MCF-7/9), and MDA-MB-435 breast carcinoma cells were cultured in EHS matrix for 12 days. Cultures were examined for the expression of integrin subunits by immunocytochemistry. The normal and tumorigenic cell lines were found to broadly recapitulate the pattern of integrin subunit expression and localization predicted from published in vivo data (Fig. 1 and Table 1). In normal HMT-3522 cells, weak staining for $\alpha 1$ was seen in the cytoplasm, and for $\alpha 2$ at the basolateral surface. Staining for the $\alpha 3$ and $\beta 1$ subunits was strong, and was localized primarily to the basolateral surface with some expression within the cytoplasm (Fig. 1A,D). Staining for the $\alpha 6$ and $\beta 4$ subunits was also strong, but the signal was restricted primarily to the basal cell surface (Fig. 1G,J). In contrast, HMT-3909/S13, MCF-7/9 and MDA-MB-435 breast carcinoma cells showed loss, disordered expression, or downregulation of these integrin subunits, and the changes appeared to correlate with the level of tumor aggression in that disordered integrin expression was most pronounced in the metastatic MDA-MB-435 cells (Fig. 1; Table 1). All tumor cells expressed $\alpha 1$ to varying degrees. Staining for $\alpha 2, \alpha 6$, and $\beta 4$ subunits was not detected on the metastatic MDA-MB-435 cells, and staining for $\alpha 3$ and $\beta 1$ was reduced. The breast carcinoma lines HMT 3909/S13 and MCF-7/9 cells showed disordered expression and/or losses of these subunits. Staining for $\alpha 2$ and $\alpha 6$ was confirmed with P1E6 and CBL-150 ( $\alpha 2)$ and J1B5 and GoH3 $(\alpha 6)$ antibodies in both normal and carcinoma cells.

\section{Formation of acinar structures within EHS is integrin dependent}

To determine which of the various integrins expressed by human breast epithelial cells are functionally relevant to the formation of acinar structures, specific inhibitory anti-integrin antibodies were used to interfere with this process in reconstituted basement membrane culture. Normal HMT-3522 cells cultured in EHS without antibodies, or with $10 \mu \mathrm{g} / \mathrm{ml}$ or $100 \mu \mathrm{g} / \mathrm{ml}$ of non-immune mouse or rat IgG, formed wellorganized acinar structures at similar frequencies, although slight increases were noted for non-immune IgGs (Table 2). In contrast, inhibitory anti$\beta 1$ subunit antibodies, at similar concentrations, severely impaired the formation of spheres by HMT-3522 cells relative to control cultures; occasional spheres were observed scattered throughout the gels, but the vast majority of the cells introduced into the EHS gels remained as suspended single cells (Fig. 2 and Table 2). These effects were observed with two different anti$\beta 1$ antibodies and were dose dependent: mouse anti- $\beta 1 \mathrm{mAb}$ (JB1a) induced a two-fold inhibition of sphere formation at $40 \mu \mathrm{g} / \mathrm{ml}$ and a 4-fold inhibition at $200 \mu \mathrm{g} / \mathrm{ml}$, whereas rat anti$\beta 1 \mathrm{mAb}$ (AIIB2) caused an almost complete inhibition at $100 \mu \mathrm{g} / \mathrm{ml}$ (Table 2; Fig. 2). Similar results were obtained at day 6 and day 12 of culture. These data suggest that sphere formation by 
normal human mammary epithelial cells in response to EHS is dependent on integrin(s) of the $\beta 1$ integrin family.

To define more precisely which integrins were critical in signaling acinar morphogenesis, similar experiments were performed with inhibitory anti- $\alpha 2,-\alpha 3$, and $-\alpha 6$ antibodies. Anti- $\alpha 3$ reduced sphere formation by $50 \%$ at $10 \mu \mathrm{g} / \mathrm{ml}$ and by $80 \%$ at $100 \mu \mathrm{g} / \mathrm{ml}$. Anti- $\alpha 5$ and anti- $\alpha 6$ antibodies were much less effective (about $70 \%$ of control) at both $10 \mu \mathrm{g} / \mathrm{ml}$ and $100 \mu \mathrm{g} / \mathrm{ml}$, while inhibitory anti- $\alpha 2$ antibodies showed no appreciable inhibition. These data indicate that, of the integrin subunits assayed, $\alpha 3 \beta 1$ appears to be the most significant in mediating morphogenesis in a basement membrane matrix. The extent of inhibition with anti- $\alpha 3$ antibodies was not equivalent to that with anti- $\beta 1$, suggesting either that $100 \mu \mathrm{g} / \mathrm{ml}$ of anti- $\alpha 3$ antibodies was not sufficient to block or that additional $\beta 1$ integrins may also be involved.

\section{Normal HMT-3522 cells utilize alternative integrins for sphere morphogenesis in collagen type I gels}

Normal mammary epithelial cells encounter basement membrane (BM) in vivo, and the data presented herein suggest that formation of acinar structures in response to BM requires $\alpha 3 \beta 1$ integrin. Previous studies have shown that the normal mammary cell line MTSV1-7 utilizes $\alpha 2 \beta 1$ integrin to form tubules and balls in response to collagen type I (Berdichevsky et al., 1992). We therefore analyzed the capacity of normal mammary cells to form spheres and deposit endogenous BM in type I collagen gels. Normal HMT-3522 cells produced well-ordered spheres in collagen gels as evidenced by morphology (Table 2; Fig. 2). However, although HMT-3522 cells basally deposited endogenous type IV collagen and laminin in reconstituted BM (as previously reported, Petersen et al., 1992), the cells did not deposit endogenous BM when cultured in type I collagen (Fig. 3). This suggests that although HMT-3522 cells are capable of forming spheres in both substrata, the level of organization of these structures is not equivalent.

The process of sphere formation by HMT-3522 cells in type I collagen gels was inhibited by 100 $\mu \mathrm{g} / \mathrm{ml}$ of inhibitory anti- $\beta 1$ antibodies to approximately the same extent as that found in EHS. Further analysis of the effects of inhibitory anti- $\alpha 2$ and $\alpha 3$, antibodies showed that in contrast to the data obtained for EHS cultures, $100 \mu \mathrm{g} / \mathrm{ml}$ of anti- $\alpha 3$ antibodies had no appreciable effect on sphere formation in collagen gels, but with anti- $\alpha 2$ approximately $50 \%$ inhibition was observed (Table 2; Fig. 2). Although this effect was analogous to $\alpha 3$ blocking in EHS, the $\alpha 2$ block in collagen was weaker than the $\beta 1$ block and also was variable. These data suggest that $\beta 1$ integrins mediate sphere formation by HMT-3522 cells in collagen gels as they do in EHS but that a different member of the $\beta 1$ family ( $\alpha 2 \beta 1$ instead of $\alpha 3 \beta 1$ ) may be preferentially used to respond to collagen.

\section{The inhibition of acinar morphogenesis by antiintegrin antibodies is associated with an inhibition of cell growth}

Previous studies with normal mammary epithelial cells using analysis of thymidine-labeling indices (TLI) have shown that an initial burst of cell growth is followed by organization of 
the cells into well-differentiated acinar structures whose growth is arrested by day 7-12 of culture (Petersen et al., 1992). The data presented in this report show that acinar formation is integrin dependent. Since normal mammary cells seeded into EHS in the presence of inhibitory antiintegrin antibodies remain suspended as single cells for the duration of the experiments, we asked whether the inhibitory antibodies interfered with acinar formation by blocking cellular growth. The thymidine-labeling indices of normal HMT-3522 cells in both EHS and collagen were determined at day 2 and day 6 of culture.

In the absence of inhibitory anti- $\beta 1$ antibodies the TLIs were approximately $60 \%$ at day 2 in both substrata but fell to 8.8\% in collagen and 3\% in EHS by day 6 as the cells formed differentiated acini. In contrast, in the presence of inhibitory anti- $\beta 1$ antibodies the cells remained suspended as single cells, and the TLIs were low at day 2 in both substrata and remained low throughout the experiment (Table 3; Fig. 4). At day 6 of culture in both substrata, the low TLIs observed in the presence of anti- $\beta 1$ antibodies reflect a small number of growth-arrested differentiated cells that formed acini by escaping the antibody blockade, and a majority of growth-inhibited single cells blocked by anti-integrin antibodies. These data suggest that an initial phase of cell growth is a requirement for acinar formation in three-dimensional culture. Thus, acinar formation appears to be a two-step process involving a $\beta 1$-integrindependent cellular growth phase, followed by a phase of cell polarization to form the final organized structures.

\section{Interruption of normal mammary cell-basement membrane interactions induces apoptosis}

Prevention of appropriate cell-ECM contact by use of nonadhesive (polyHEMA) coated substrata, ECM fragments or RGD peptides can inhibit cell growth and differentiation in anchorage-dependent cells (Hayman et al., 1985; Ingber, 1990) and trigger programmed cell death or apoptosis (Frisch and Francis, 1994). Data presented herein show that inhibition of mammary cell attachment to basement membrane by ligation of $\beta 1$ integrins blocks cellular growth and acinar formation. We therefore asked whether the inhibition of mammary cellBM interaction induces apoptosis. Normal HMT-3522 cells were embedded within EHS matrix in the presence or absence of function-blocking anti- $\beta 1$ antibodies and assayed for evidence of apoptosis at day 2 and day 6 of culture by detection of FITC-digoxigenin nucleotide labelling of 3'OH DNA ends using the ApopTag in situ apoptosis detection kit.

In the absence of anti- $\beta 1$ antibodies, HMT-3522 cells formed acinar structures as described above. Apoptotic nuclei were detected infrequently (0.74\%) at day 2, whereas at day 6, 6.3\% of single cells not incorporated into acini and $2.5 \%$ of individual cells within acini were stained with the ApopTag reagents (Fig. 5). In contrast, in the presence of anti- $\beta 1$ antibodies, $20.9 \%$ of the cells contained nuclei stained by ApopTag reagents at day 2 and at day 6, 59.9\% of the nuclei were labelled. Interestingly, a small number of acini ( $\sim \%$ of control) formed in the presence of inhibitory anti- $\beta 1$ integrin (see Table 2 ). The cells within these acini did not contain nuclei stained with the ApopTag reagents.

These data suggest strongly that $\beta 1$ integrins transmit signals from ECM that are required for survival. 


\section{Inhibitory anti-integrin subunit antibodies do not block colony formation by breast carcinoma cells in reconstituted basement membrane}

To determine whether the formation of colonies by breast carcinoma cells in reconstituted basement membrane reflects a failure of the cells to sense BM correctly, the effects of inhibitory anti-integrin antibodies were tested on HMT-3909/S13 and MDA-MB-435 cells. We found that inhibitory anti- $\beta 1$ antibodies did not inhibit the capacity of tumor cells to make colonies within EHS at $100 \mu \mathrm{g} / \mathrm{ml}$; the concentration that inhibited acinar formation by normal cells (Table 4A). Furthermore, anti- $\alpha 2$, $-\alpha 3$, and $-\alpha 6$ antibodies were also ineffective, although in the presence of anti- $\alpha 3$ the MDA-MB-435 cells appeared to send out more cellular processes at the margins of the tumor colonies (data not shown).

We then asked whether inhibitory anti-integrin antibodies could influence the growth properties of breast carcinoma cells or induce apoptosis in three-dimensional culture. HMT-3909/S13, MDA-MB-435 and MCF-7/9 cells were cultured in Matrigel for 6 days in the presence or absence of anti- $\beta 1$ integrin antibodies. Growth was assessed by $[3 \mathrm{H}] \mathrm{TdR}$ autoradiography and apoptosis was evaluated by detection of FITCdigoxigenin nucleotide labelling of 3'OH DNA ends using the ApopTag in situ apoptosis detection kit. Control cultures (no antibodies) of HMT3909/S13 and MDA-MB-435 carcinoma cells showed moderate TLIs of approximately 10\%, whereas MCF-7/9 cells grew more aggressively, with a TLI of 25\%. No inhibition of cellular growth was observed in the presence of inhibitory anti- $\beta 1$ antibodies (Table 4B). In fact slight increases in labeling indices were noted for HMT-3909/S13 and MCF-7/9 cells. The percentages of nuclei stained with ApopTag reagents for these three carcinoma lines were $4.85 \%$, $0 \%$, and $<1 \%$, respectively, without antibodies and $5.6 \%,<1 \%$ and $<1 \%$ with inhibitory antibodies. These data demonstrate that, even though certain integrin subunits are expressed in these carcinoma cell lines (Table 1, Fig. 1), interfering with their function does not block cell growth, inhibit colony formation or induce apoptosis in these cells (Fig. 6).

\section{Discussion}

Interactions between mammary epithelium and extracellular matrix have been shown to be critical to mammary-specific growth and differentiation. Mouse and human mammary epithelial cells cultured on, or within, reconstituted basement membrane undergo a process of morphogenesis to form polarized acinar structures that secrete sialomucins and milk proteins apically and deposit basement membrane components basally. Tumor cells, on the other hand, fail to recapitulate this process and produce large, poorly differentiated colonies. These data suggest that interactions between mammary epithelial cells and their microenvironment are important in regulating normal cellular functions and that these interactions are disturbed in tumorigenesis.

Interactions with ECM are mediated by integrins, and there is evidence in mouse cells that $\beta 1$ integrin signaling is involved in mammary epithelial differentiation in culture in response to basement membrane (Streuli et al., 1991). The basement membrane response is now known to be mediated by laminin (Streuli et al., 1995). 
Human mammary epithelial cells in vivo express several integrins that recognize laminin. The expression of these integrins has been found altered in the majority of human breast carcinomas studied and the severity of receptor losses or downregulation correlates with tumor grade (Pignatelli et al., 1991; Koukoulis et al., 1991, 1993). This suggests that dysregulation of integrin expression may be an important parameter in breast tumorigenesis. Our analysis of the profile of integrin subunit expression in normal HMT-3522 cells and three breast carcinoma cell lines, HMT-3909/S13, MCF-7/9 and MDA-MB-435, following culture in reconstituted basement membrane, broadly agrees with published in vivo observations. Normal HMT-3522 cells showed weak expression of $\alpha 1$ in the cytoplasm and $\alpha 2$ at the basolateral surface, and abundant expression of $\alpha 3$ and $\beta 1$, primarily at the basolateral surface, and $\alpha 6$ and $\beta 4$ at the basal cell surface. These data suggest that $\alpha 2 \beta 1, \alpha 3 \beta 1, \alpha 6 \beta 4$ and potentially $\alpha 6 \beta 1$ are the major integrins for laminin expressed in HMT-3522 cells. The significance of the $\alpha 1$ integrin staining in the HMT-3522 cells is not clear as previous reports have demonstrated $\alpha 1$ localization in both luminal epithelial (Koukoulis et al., 1993) and myoepithelial cells of the breast (Lazard et al., 1993; O. W. Petersen, unpublished observations). The breast carcinoma cell lines HMT3909/S13, MCF-7/9 and MDAMB-435 showed loss, disordered expression, or downregulation of these integrin subunits. The changes were most severe in the metastatic MDA-MB-435 cells, suggesting a correlation between dysregulation of integrin expression and aggressive tumor behavior consistent with the in vivo survey data discussed above. These data validate our reconstituted basement membrane assay, provide new markers of differentiation to distinguish normal and malignant breast epithelial cells in our 3-D assay, and provide a basis for evaluating the functional roles of integrins in mediating signals from ECM for mammary-specific differentiation in culture.

The formation of polarized acinus-like spheres is one parameter of normal mammary function that is regulated by basement membrane. This morphogenesis has been shown in turn to be required for biosynthetic aspects of mammary differentiation, including the expression of the milk whey acidic protein in mouse cells (Chen and Bissell, 1989; Lin and Bissell, 1993), apical secretion of sialomucin, and formation of endogenous basement membrane in human breast cells (Petersen et al., 1992; Howlett et al., 1994). Through the use of specific inhibitory anti-integrin antibodies, we have shown that the morphogenesis of acinar structures by normal breast epithelial cells is dependent on integrins. Inhibitory antibodies specific for the $\beta 1$ integrin subunit virtually abolished the sphere-forming capacity of normal HMT-3522 cells in both reconstituted basement membrane and in type I collagen gels. Preliminary data with another normal mammary epithelial cell line MCF-10A (Soule et al., 1990) showed similar trends (data not shown). These data suggest that integrins are involved in a general mechanism by which mammary epithelial cells perceive morphogenetic signals from the ECM. Our experiments with inhibitory anti- $\alpha$ subunit antibodies suggest a specificity of integrin signaling that is dependent on the nature of the ECM presented to the cells. The $\alpha 2 \beta 1$ receptor may be preferentially utilized for interactions with collagen which is consistent with data showing that $\alpha 2 \beta 1$ mediates the morphogenesis of MTSV1-7 breast epithelial cells (Berdichevsky et al., 1992, 1994; D’Souza et al., 1993) and the well differentiated breast carcinoma cell line T47D (Keely et al., 1995) induced by type 1 collagen. In contrast, $\alpha 3 \beta 1$ may be preferred for interactions with basement membrane. Both receptors recognize laminin and collagen (Hynes, 1992). Thus, the lack of inhibition of HMT-3522 morphogenesis by anti- $\alpha 2$ antibody in EHS and anti$\alpha 3$ antibody in collagen suggests that mammary cells can modulate either the expression of these 
receptors or their binding affinities depending on the ECM ligands encountered. Support for the latter possibility was provided by observations on MTSV1-7 cells transformed by the c-erb-B2 gene in which losses of $\alpha 2 \beta 1$, but not $\alpha 3 \beta 1$, lead to a failure to undergo morphogenesis in collagen gels (D’Souza et al., 1993). This suggests that although MTSV1-7 cells have $\alpha 3 \beta 1$ integrin, they do not use this receptor for formation of 3-dimensional structures in collagen. The lack of inhibitory effects of the anti- $\alpha 6$ antibody GoH3 on sphere formation is consistent with the lack of inhibition of basement membrane-induced $\beta$-casein expression in mouse mammary cells using this antibody (Streuli et al., 1991) and suggests that $\alpha 6 \beta 1$ may not be critical to mammary differentiation in response to BM. However, $\alpha 6 \beta 1$ integrin may be important in other tissues such as the lung, since the E8 fragment of laminin which binds to $\alpha 6 \beta 1$ (Sonnenberg et al., 1990), is involved in signaling lung alveolar morphogenesis by basement membrane (Matter and Laurie, 1994). The $\alpha 3 \beta 1$ integrin binds the E3 fragment of laminin (Gehlsen et al., 1992), rather than E8 and it was recently shown that a domain within E3 is required for the induction of $\beta$-casein in mouse mammary cells (Streuli et al., 1995). Although direct evidence for a role for $\alpha 3 \beta 1$ in $\beta$-casein expression is lacking, these data further suggest a role for $\alpha 3 \beta 1$ in basement membrane-induced functions of mammary cells.

The laminin form found in EHS matrix (laminin 1) is known to be a weak ligand for $\alpha 3 \beta 1$ integrin, whereas kalinin (laminin 5) shows much stronger affinity for this receptor (Weitzman et al., 1993). Thus, although our data indicate that acinar morphogenesis by mammary cells can be driven by EHS, a role for endogenous BM rich in kalinin or another laminin isoform, cannot be discounted. Our analysis of the capacity of HMT-3522 cells to deposit endogenous BM showed that while both EHS and type 1 collagen can support the formation of spheres, the deposition of endogenous BM was induced in EHS only. These data indicate that endogenous BM is not necessary for sphere formation, but that the level of sphere organization is different in the two substrata. The data also indicate that both type 1 collagen and reconstituted BM can downregulate growth. These data fit with studies on well and poorly differentiated pancreatic carcinoma cell lines cultured in matrigel and type I collagen where endogenous BM deposition was found in matrigel only (Yamanari et al., 1994). While this point is not emphasised, their data also indicate that the formation of 3-D structures in the two substrata is not the same - the cells with a capacity for differentiation are more differentiated in matrigel than in type 1 collagen.

We have observed a growth-inhibitory effect associated with the anti-integrin-mediated block to acinar morphogenesis in EHS matrix and collagen I. Inhibitory anti- $\beta 1$ integrin antibodies severely inhibited the growth of HMT-3522 cells such that the cells remained in suspension as single cells for the duration of the experiment. Similar results were obtained with MCF-10A cells (data not shown). These data suggest that the initial pulse of cellular growth observed prior to growth arrest for normal cells in EHS and collagen I (Petersen et al., 1992, and data presented herein) is a prerequisite for acinar morphogenesis by mammary epithelial cells under our present assay conditions where cells are seeded at low density. Previous reports of continuous propagation of normal human mammary epithelial cells in collagen gels (Yang et al., 1982; Sakthivel et al., 1993) may reflect differences in media composition and/or cell densities within the gels. If the pulse of growth observed in our assay is prevented by ligating ECM receptors with inhibitory anti- $\beta 1$ integrin antibodies, the cells undergo apoptosis. These data support the hypothesis that if integrin-mediated contact with ECM is denied, the cells can neither grow nor 
differentiate and are unable to survive (Frisch and Francis, 1994; Boudreau et al., 1995; for review see Ruoslahti and Reed, 1994).

An important characteristic of tumors, in addition to loss of growth control, is disrupted tissue histoarchitecture and changes in adhesive cellular interactions as well as cell-ECM interactions. The inability of tumors to produce organized three-dimensional structures in culture has been observed both in reconstituted BM (Petersen et al., 1992,) and collagen gels (Shearer et al., 1992). Most significantly, our data with inhibitory antibodies show that formation of colonies by three breast carcinoma cell lines (HMT-3909/S13, MCF7/9 and MDA-MB-435) proceeds in the presence of inhibitory antiintegrin antibodies. That the antibodies did not inhibit carcinoma cell growth or induce apoptosis suggests that tumor colony formation occurs independently of the integrin signaling utilized by normal cells to produce acinar structures in reconstituted basement membrane. The variable, disordered expression of integrin subunits on the carcinoma cells suggest that those integrins that are present are either insufficient in quantity, improperly localized to deliver a signal to the cell, or otherwise inactive. However, it is highly unlikely that $\beta 1$ integrins are entirely nonfunctional in these cells, since our previous studies indicate that in the absence of serum, all three of the tumor cell lines required type 1 collagen to adhere and to grow in a 2-dimensional monolayer culture.

Taken together, our data demonstrate that normal breast epithelial cells form acinus-like structures from single cells by a process that involves at least two distinct phases: (1) growth; and (2) conversion of the cell group into differentiated structures. The growth phase is $\beta 1$ integrin-dependent; if the cells are deprived of the BM signal, the cells enter an apoptotic pathway. In contrast, breast carcinoma cells form disordered colonies independently of $\beta 1$ integrins; cellular growth is not inhibited and apoptosis is not induced by antibody blockade. Thus, defects in cellular responses to microenvironment, including ECM, may be an important parameter of malignancy in addition to other established genetic lesions. Consistent with the above is the observation that elevation of the expression of the $\alpha 5 \beta 1$ receptor for fibronectin by transfection into tumorigenic Chinese hamster ovary cells leads to increases in fibronectin deposition, restoration of anchorage dependence and inhibition of tumorigenicity (Giancotti and Ruoslahti, 1990).

Our data demonstrate that integrins play an active role in both the growth and survival of normal human breast cells. We believe this is also the the first demonstration that tumor cells do not use $\beta 1$-containing integrins for either of these processes. The mechanisms by which breast carcinoma cells escape integrin-mediated regulation of growth and apoptosis remain to be determined and elucidation of this process will be a valuable step toward further understanding the nature of human breast malignancy.

\section{Acknowledgments}

We thank Jody Brink for expert technical assistance. This work was supported by the US Army Medical Research and Development, Acquisition and Logistics Command (Prov), the Health Effects Research Division, Office of Health and Environmental Research, US Department of Energy under contract DE-ACO3-76SF00098, the START program of the Danish Research Council, the Danish Cancer Society, the Novo Foundation, the Meyer Foundation, the Thaysen 
Foundation, the Wedell-Wedellsborg foundation, the Gangsted Foundation, and the National Institutes of Health (CA 42032). Opinions, interpretations, conclusions and recommendations are those of the authors and are not necessarily endorsed by the US Army.

\section{References}

Adams, J. C. and Watt, F. M. (1993). Regulation of development and differentiation by extracellular matrix. Development 117, 1183-1198

Berdichevsky, F., Gilbert, C., Shearer, M. and Taylor-Papadimitriou, J. (1992). Collageninduced rapid morphogenesis of human mammary epithelial cell: the role of the alpha 2-beta 1 integrin. J. Cell Sci. 102, 437-446.

Berdichevsky, F., Wetzels, R., Shearer, M., Martignone, S., Ramaekers, F. C. S. and Taylor-Papadimitriou, J. (1994). Integrin expression in relation to cell phenotype and malignant change in the human breast. Mol. Cell. Differ. 2, 255-274.

Blaschke, R. J., Howlett, A. R., Desprez, P.-Y., Petersen, O. W. and Bissell, M. J. (1995). Cell differentiation by extracellular matrix components. In Extracellular Matrix Components. Methods in Enzymology, vol. 245 (ed. E. Rouslahti and E. Engval) (in press).

Boudreau, N., Sympson, C. J., Black, R., Werb, Z. and Bissell, M. J. (1995). Extracellular matrix suppresses expression of interleukin-1 $\beta$ converting enzyme and apoptosis in mammary epithelial cells. Science 267, 891-893.

Briand, P., Petersen O. W. and van Deurs B. (1987). A new diploid nontumorigenic human breast epithelial cell line isolated and propagated in chemically defined medium. In Vitro Cell. Dev. Biol. 23, 181-188.

Chen, L.-H. and Bissell, M. J. (1989). A novel regulatory mechanism for whey acidic protein gene expression. Cell Regul. 1, 45-54.

Chiquet-Ehrismann, R., Mackie, E. J., Pearson, C. A. and Sakakura, T. (1986). Tenascin: An extracellular matrix protein involved in tissue interactions during fetal development and carcinogenesis. Cell 47, 131-139.

D’Ardenne, A. J., Richman, P. I., Horton, M. A., McAuley, A. E. and Jordon, S. (1991). Coordinate expression of the $\alpha 6$ integrin laminin receptor sub-unit and laminin in breast cancer. $J$. Pathol. 165, 213-220.

D'Souza, B., Berdichevsky, F., Kyprianou, N. and Taylor-Papadimitriou, J. (1993). Collagen-induced morphogenesis and expression of the $\alpha 2$-integrin subunit is inhibited in cerbB2-transfected human mammary epithelial cells. Oncogene 8, 1797-1806.

Damsky, C. H., Fitzgerald, M. L. and Fisher, S. L. (1992). Distribution patterns of extracellular matrix components and adhesion receptors are intricately modulated during first trimester cytotrophoblast differentiation along the invasive pathway in vivo. J. Clin. Invest. 89, 210-222.

Damsky, C. H. and Werb, Z. (1992). Signal transduction by integrin receptors for extracellular matrix: cooperative processing of extracellular information. Curr. Opin. Cell Biol. 4, 772-781.

Frisch, S. M. and Francis, H. (1994). Disruption of epithelial cell-matrix interactions induces apoptosis. J. Cell Biol. 124, 619-626.

Gehlsen, K. R., Sriramarao, P., Furcht, L. T. and Skubitz, A. P. N. (1992). A synthetic peptide derived from the carboxy terminus of the laminin A chain represents a binding site for the $\alpha 3 \beta 1$ integrin. J. Cell Biol. 117, 449-459. 
Giancotti, F. G. and Ruoslahti, E. (1990). Elevated levels of the $\alpha 5 \beta 1$ fibronectin receptor suppress the transformed phenotype of Chinese hamster ovary cells. Cell 60, 849-859.

Haslam, S. Z. (1991). Stromal-epithelial interactions in normal and neoplastic mammary gland. In Regulatory Mechanisms in Breast Cancer (ed. M. Lippman and R. Dickson), pp. 401-420. Hingham: Kluwer.

Hay, E. D. (1993). Extracellular matrix alters epithelial differentiation. Curr. Opin. Cell Biol. 5, 1029-1035

Hayman, E. G., Pierschbacher, M. D. and Ruoslahti, E. (1985). Detachment of cells from culture substrate by soluble fibronectin peptides. J. Cell Biol. 100, 1948-1954.

Howlett, A. R. and Bissell, M. J. (1993). The influence of tissue microenvironment (stroma and extracellular matrix) on the development and function of mammary epithelium. Epithelial Cell Biol. 2, 79-89.

Howlett, A. R., Petersen, O. W., Steeg, P. S. and Bissell, M. J. (1994). A novel function for the $n m 23-H 1$ gene: Overexpression in human breast carcinoma cells leads to the formation of basement membrane and growth arrest. J. Nat. Cancer Inst. 86, 1838-1844.

Hynes, R. O. (1992). Integrins: Versatility, modulation and signaling in cell adhesion. Cell 69, 11-25.

Ingber, D. E. (1990). Fibronectin controls capilliary endothelial cell growth by modulating cell shape. Proc. Nat. Acad. Sci. USA 87, 3579-3583.

Jones, J. L., Critchley, D. R. and Walker, R. A. (1992). Alteration of stromal protein and integrin expression in breast - a marker of premalignant change? J. Pathol. 167, 399-406.

Juliano, R. L. and Haskill, S. (1993). Signal transduction from the extracellular matrix. J. Cell Biol. 120, 577-585.

Keely, P. J., Fong A. M., Zutter M. M. and Santoro S. A. (1995). Alteration of collagendependent adhesion, motility, and morphogenesis by the expression of anti-sense $\alpha 2$ integrin mRNA in mammary cells. J. Cell Sci. 108, 595-607.

Koukoulis, G. K., Virtanen, I., Korhonen, M., Laitinen, L., Quaranta, V. and Gould, V. E. (1991). Immunohistochemical localization of integrins in the normal, hyperplastic and neoplastic breast. Am. J. Pathol. 139, 787-799.

Koukoulis, G. K., Howeedy, M., Korhonen, M., Virtanen I. and Gould, V. E. (1993).

Distribution of tenascin, cellular fibronectins and integrins in the normal, hyperplastic and neoplastic breast. J. Submicrosc. Cytol. Pathol. 25, 285-295.

Lazard, D., Sastre, X., Frid, M. G., Glukhova, M. A., Thiery, J.-P. and Koteliansky, V. E. (1993). Expression of smooth muscle-specific proteins in myoepithelium and stromal myofibroblasts of normal and malignant human breast tissue. Proc. Nat. Acad. Sci. USA 90, 9991003

Lee, E. Y.-H., Parry, G. and Bissell, M. J. (1984). Modulation of secreted proteins of mouse mammary epithelial cells by the collagenous substrata. J. Cell Biol 98, 146-155

Lin, C. Q. and Bissell, M. J. (1993). Multifaceted regulation of cell differentiation by extracellular matrix. FASEB J. 7, 737-743.

Matter, M. L. and Laurie, G. W. (1994). A novel laminin E8 cell adhesion site required for lung alveolar formation in vitro. J. Cell Biol. 124, 1083-1090.

Natali, P. G., Nicotra, M. R., Botti, C., Mottolese, M., Bigotti, A. and Segatto, O. (1992).

Changes in expression of $\alpha 6 \beta 4$ integrin heterodimer in primary and metastatic breast cancer. $\mathrm{Br}$. J. Cancer 66, 318-322. 
Petersen, O. W., Rønnov-Jessen, L., Howlett, A. R. and Bissell, M. J. (1992). Interaction with basement membrane serves to rapidly distinguish growth and differentiation pattern of normal and malignant human breast epithelial cell. Proc. Nat. Acad. Sci. USA 89, 9064-9068.

Pignatelli, M., Hanby, A. M. and Stamp, G. W. H. (1991). Low expression of $\beta 1$, $\alpha 2$, and $\alpha 3$ subunits of VLA integrins in malignant mammary tumors. J. Pathol. 165, 25-32.

Pignatelli, M., Cardillo, M. R., Hanby, A. M. and Stamp, G. W. H. (1992). Integrins and their accessory adhesion molecules in mammary carcinomas: Loss of polarization in poorly differentiated tumors. Human Pathol. 23, 1159-1166.

Roskelley, C. D., Petersen, O. W. and Bissell, M. J. (1993). The significance of the extracellular matrix in mammary epithelial carcinogenesis. In Advances in Molecular and Cell Biology, vol. 7 (ed. G. Heppner), pp. 89-113. New York: JAI Press.

Ruoslahti, E. and Reed, J. C. (1994). Anchorage dependence, integrins, and apoptosis. Cell 77, 477-478.

Sakthivel, R., Hamdan, M., Yang, J., Guzman, R. C. and Nandi, S. (1993). Effect of TGFalpha on growth of normal human breast epithelial cells in serum-free culture using 3dimensional collagen gels. Cell Biology Int. Rep. 17, 387-397

Shearer, M., Bartkova, J., Bartek, J., Berdichevsky, F., Barnes, S. D., Millis, R. and TaylorPapadimitriou, J. (1992). Studies of clonal cell lines developed from primary breast cancers indicate that the ability to undergo morphogenesis in vitro is lost early in malignancy. Int. $J$. Cancer 51, 602-612.

Sonnenberg, A., Linders, C. J., Modderman, P. W., Damsky, C. H., Aumailley, M. and Timpl, R. (1990). Integrin recognition of different cellbinding fragments of laminin (P1, E3, E8) and evidence that $\alpha 6 \beta 1$ but not $\alpha 6 \beta 4$ functions as a major receptor for fragment E8. J. Cell Biol. 110, 2145-2155

Soule, H. D., Maloney, T. M., Wolman, S. R., Peterson Jr, W. D., Brenz, R., McGrath, C. M., Russo, J., Pauley, R. J., Jones, R. F. and Brooks, S. C. (1990). Isolation and characterization of a spontaneously immortalized human breast epithelial cell line MCF-10. Cancer Res. 50, 6075-6086.

Stoker, A. W., Streuli, C. H., Martins-Green, M. and Bissell, M. J. (1990). Designer microenvironments for the analysis of cell and tissue function. Curr. Opin. Cell Biol. 2, 864-874. Streuli, C. H., Bailey, N. and Bissell, M. J. (1991). Control of mammary epithelial differentiation: Basement membrane induces tissue specific gene expression in the absence of cell-cell interaction and morphological polarity. J. Cell Biol. 115, 1383-1395.

Streuli, C. H., Schmidhauser, C., Bailey, N., Yurchenco, P., Skubitz, A. P. N. Roskelley, C. D. and Bissell, M. J. (1995). A domain within laminin that mediates tissue-specific gene expression in mammary epithelia. J. Cell Biol. (in press).

Sympson, C. J., Talhouk, R. S., Alexander, C. M., Chin, J. R. Clift, S. M., Bissell, M. J. and Werb, Z. (1994). Targeted expression of stromelysin-1 in mammary gland provides evidence for a role of proteinases in branching morphogenesis and the requirement for an intact basement membrane for tissue-specific gene expression. J. Cell Biol. 125, 681-693

Weitzman, J. B., Pasqualini, R., Takada, Y. and Hemler, M. E. (1993). The function and distinctive regulation of the integrin VLA-3 in cell adhesion, spreading, and homotypic cell aggregation. J. Biol. Chem. 268, 8651-8657.

Werb, Z., Tremble, P. M., Behrendtsen, O., Crowley, E. and Damsky, C. H. (1989). Signal transduction through the fibronectin receptor induces collagenase and stromelysin gene expression. J. Cell Biol. 109 877-889. 
Yamanari, H., Suganuma, T., Iwamura, T., Kitamura, N., Taniguchi, S. and Setoguchi, T. (1994). Extracellular matrix components regulating glandular differentiation and the formation of basal lamina of a human pancreatic cancer cell line in vitro. Exp. Cell Res. 211, 175-182.

Yang, J., Larson, L., Flynn, D., Elias, J. and Nandi, S. (1982). Serum-free primary culture of human normal mammary epithelial cells in collagen gel matrix. Cell Biology International Reports 6, 969-975

Zutter, M. M., Mazoujian, G. and Santoro, S. A. (1990). Decreased expression of integrin adhesive protein receptors in adenocarcinoma of the breast. Am. J. Pathol. 137, 863-870.

Zutter, M. M., Krigman, H. R. and Santoro, S. A. (1993). Altered integrin expression in adenocarcinoma of the breast. Analysis by in situ hybridization. Am. J. Pathol. 142, 1439-1448. 
Figures and Tables

Table 1

Table 1. Summary of immunolocalization of integrin subunits in human breast epithelial cells cultured in EHS matrix

\begin{tabular}{|c|c|c|c|c|c|c|}
\hline \multirow[b]{2}{*}{ Cell line } & \multicolumn{6}{|c|}{ Integrin subunit } \\
\hline & $\begin{array}{c}\alpha 1 \\
(\mathrm{AB} 1934)\end{array}$ & $\begin{array}{c}\alpha 2 \\
\text { (P1E6; } \\
\text { CLB-150) }\end{array}$ & $\begin{array}{c}\alpha 3 \\
\text { (P1B5) }\end{array}$ & $\begin{array}{c}\alpha 6 \\
\text { (J1B5; } \\
\text { GoH3) }\end{array}$ & $\begin{array}{c}\beta 1 \\
\text { (AIIB2) }\end{array}$ & $\begin{array}{c}\beta 4 \\
(3 \mathrm{E} 1)\end{array}$ \\
\hline HMT-3522 & $\pm^{*}$ & $\pm \dagger$ & $+++^{*}, \dagger$ & $++++\ddagger$ & $+++\dagger$ & ++++ \\
\hline HMT-3909 & $+*$ & - & $+++^{*}, \dagger$ & $\pm^{*}, \pm$ & ++++ & $-\S$ \\
\hline MCF-7/9 & $+^{*}$ & - & $\pm^{*}, \dagger$ & $-\tau^{+}$ & \pm & - \\
\hline $\begin{array}{l}\text { MDA- } \\
\text { MB-435 }\end{array}$ & $\pm *$ & $-\S$ & $\pm^{*}$ & $-\S$ & $\pm^{*}$ & $-\S$ \\
\hline $\begin{array}{l}\text { *Cytopla } \\
\text { †Basolate } \\
\text { †Basal lo } \\
\S \text { Some ve } \\
\text { "Weak cy }\end{array}$ & $\begin{array}{l}\text { smic localiz: } \\
\text { eral localizat } \\
\text { calization. } \\
\text { ery weak cyt } \\
\text { toplasmic st }\end{array}$ & $\begin{array}{l}\text { tion. } \\
\text { on. } \\
\text { plasmic stai } \\
\text { aining with J }\end{array}$ & $\begin{array}{l}\text { hing. } \\
1 \mathrm{~B} 5 \text { but }\end{array}$ & tly ne & e with & H3. \\
\hline
\end{tabular}


Table 2

Table 2. Effect of function-blocking anti-integrin antibodies on sphere formation by normal mammary epithelial cells

\begin{tabular}{|c|c|c|c|c|c|c|}
\hline \multirow[b]{2}{*}{ Substratum } & \multicolumn{6}{|c|}{$\begin{array}{l}\text { Percentage of acinar structures formed } \\
\text { within three-dimensional substrata }\end{array}$} \\
\hline & $\begin{array}{c}\text { Non- } \\
\text { immune } \\
\text { mouse IgG }\end{array}$ & $\begin{array}{l}\text { Non- } \\
\text { immune } \\
\text { rat IgG }\end{array}$ & $\begin{array}{l}\text { Mouse } \\
\text { anti- } \alpha 2\end{array}$ & $\begin{array}{l}\text { Mouse } \\
\text { anti- } \alpha 3\end{array}$ & $\begin{array}{c}\text { Rat } \\
\text { anti- } \alpha 6\end{array}$ & $\begin{array}{c}\text { Rat } \\
\text { anti- } \beta 1\end{array}$ \\
\hline HS matrix & $93.7 \pm 19.4$ & $124 \pm 24$ & $106.8 \pm 31$ & $20.8 \pm 15$ & $71.3 \pm 10$ & $6.4 \pm$ \\
\hline Collagen I & $130 \pm 21.4$ & $123 \pm 25.7$ & $51.8 \pm 21$ & $109 \pm 43$ & ND & \\
\hline \multicolumn{7}{|c|}{$\begin{array}{l}\text { Normal mammary cells (HMT-3522) were cultured in EHS or type } 1 \\
\text { collagen matrix for a minimum of } 6 \text { days. The number of mature acinus-like } \\
\text { spheres was scored microscopically in } 10 \text { random low power fields. Sphere } \\
\text { frequency is expressed as a percentage relative to control cultures (no } \\
\text { antibodies); values are means } \pm \text { s.d. Anti- } \alpha 2 \text { (P1E6); anti- } \alpha 3 \text { (P1B5); anti- } \alpha 6 \\
\text { (GoH3) and anti- } \beta 1 \text { (AIIB2) integrin subunit antibodies and control Igs were } \\
\text { used at } 100 \mu \mathrm{g} / \mathrm{ml} \text {. ND, not determined. }\end{array}$} \\
\hline
\end{tabular}




\section{FIGURE 1}

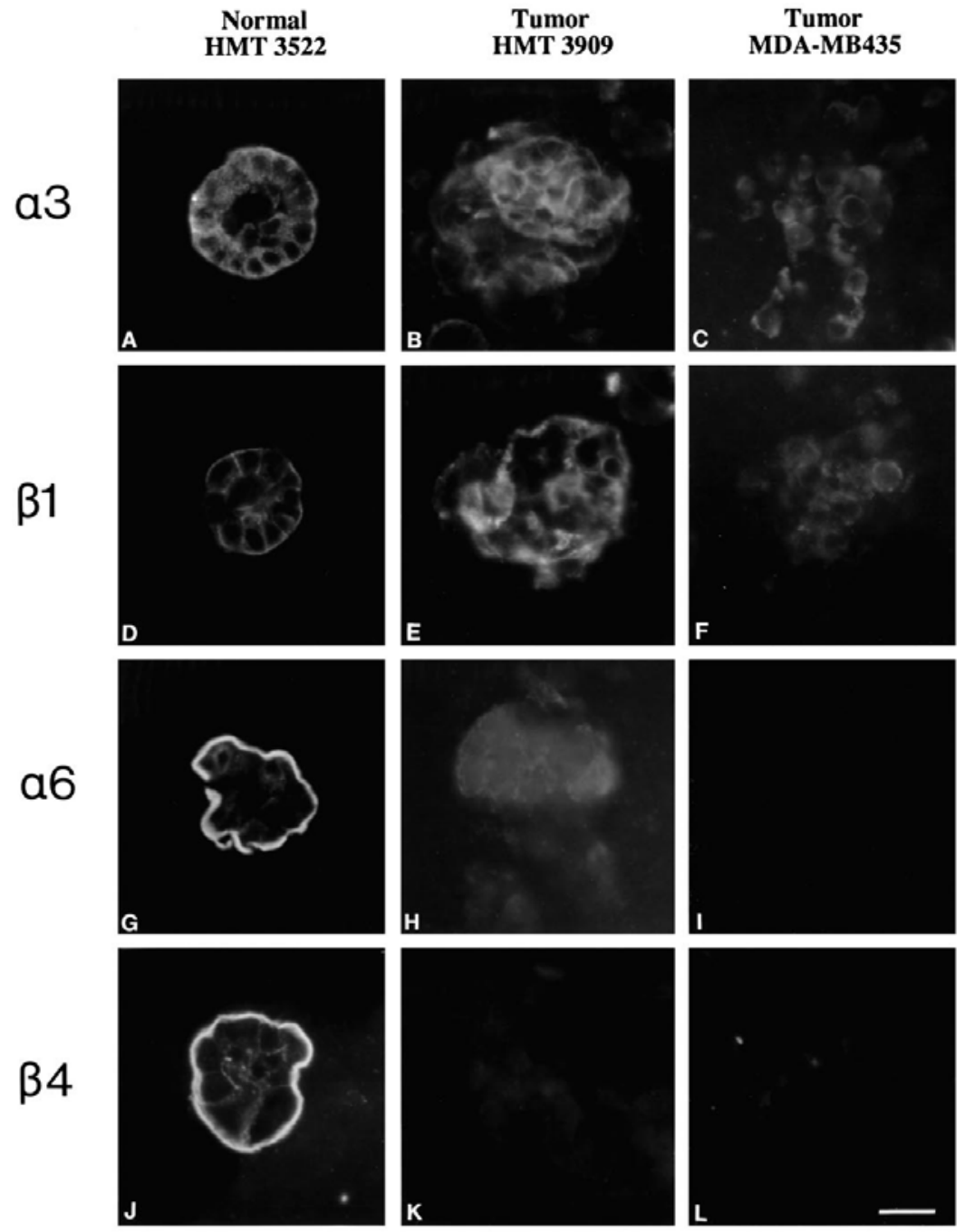

Expression of laminin receptor integrin subunits by normal human mammary cells and tumor cells within EHS matrix. Normal and malignant human mammary epithelial cells were cultured within EHS for 12 days. The $\alpha 3$ (A-C), $\beta 1$ (D-F), $\alpha 6$ (G-I), and $\beta 4$ (J-L) integrin subunits were localized by immunofluorescence in $5 \mu \mathrm{m}$ frozen sections using antibodies P1B5, AIIB2, J1B5 and 3E1, respectively. Normal HMT-3522 cells show basolateral expression of $\alpha 3$ and $\beta 1$ (A,D), whereas the carcinoma cells show diffuse cytoplasmic localization of approximately equal (HMT-3909/S13, B,E) or greatly diminished (MDA-MB-435, C,F) intensity. Normal HMT-3522 cells show strong basal staining for $\alpha 6$ and $\beta 4(\mathrm{G}, \mathrm{J})$, whereas tumor cells show variable weak cytoplasmic staining (HMT-3909/S13, H,K) or almost no staining at all (MDA-MB-435, I,L). Bar, $21 \mu \mathrm{m}$. 
FIGURE 2
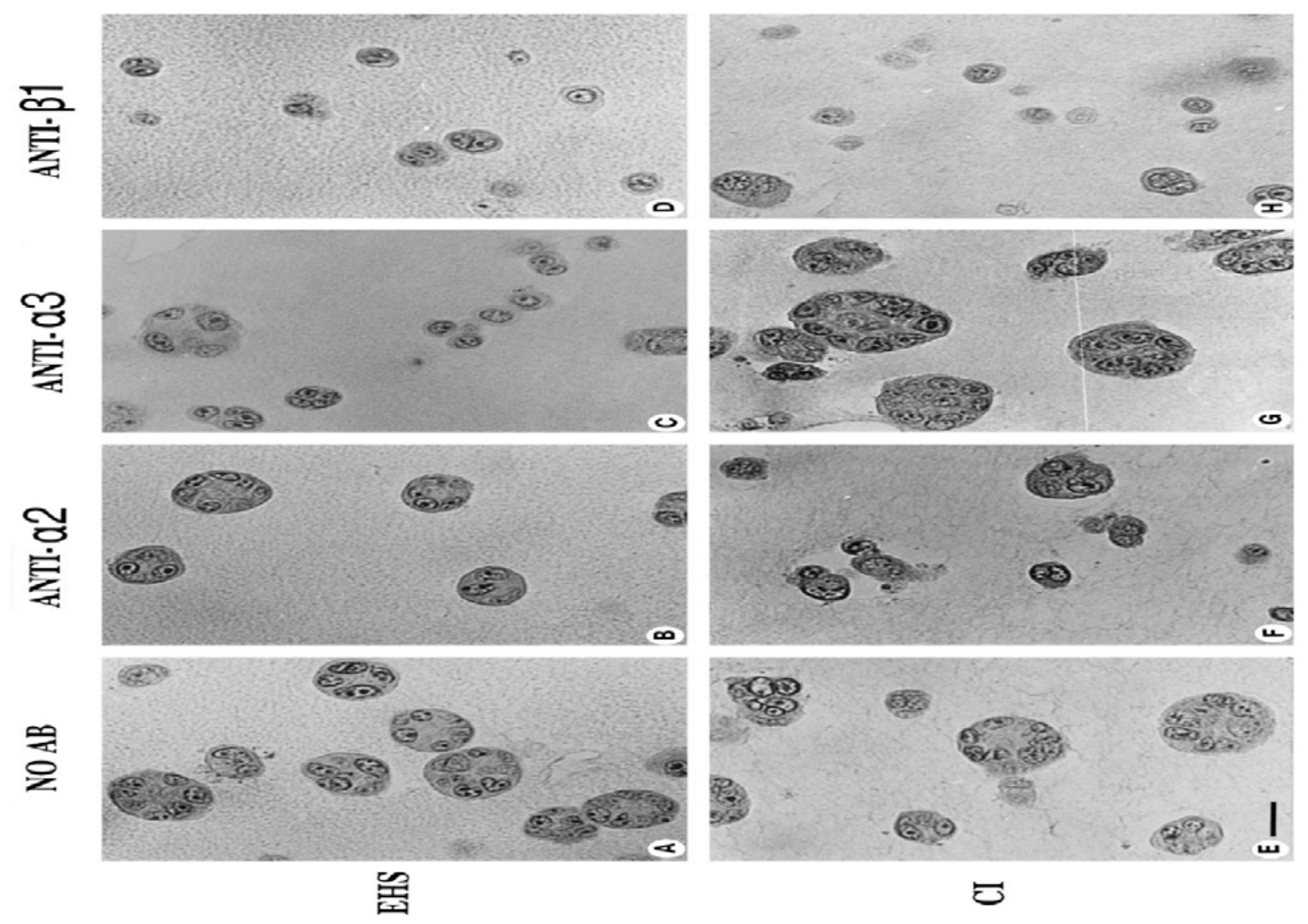

Formation of acinar structures by normal HMT-3522 cells in both EHS and type 1 collagen gels by day 6 of culture (A,E). In the presence of $100 \mu \mathrm{g} / \mathrm{ml}$ inhibitory anti- $\beta 1$ subunit antibodies (clone AIIB2) formation of acinus-like spheres is severly hampered (D,H). In EHS culture 100 $\mu \mathrm{g} / \mathrm{ml}$ anti- $\alpha 3$ (clone P1B5), but not $100 \mu \mathrm{g} / \mathrm{ml}$ anti- $\alpha 2$ (clone P1E6), antibodies interfere with the formation of acini (B,D), whereas in collagen gels the reverse applies in that inhibitory anti$\alpha 2$ blocks sphere formation but anti- $\alpha 3$ does not (F,G). Bar, $26 \mu \mathrm{m}$. 
FIGURE 3

\section{DAPI}

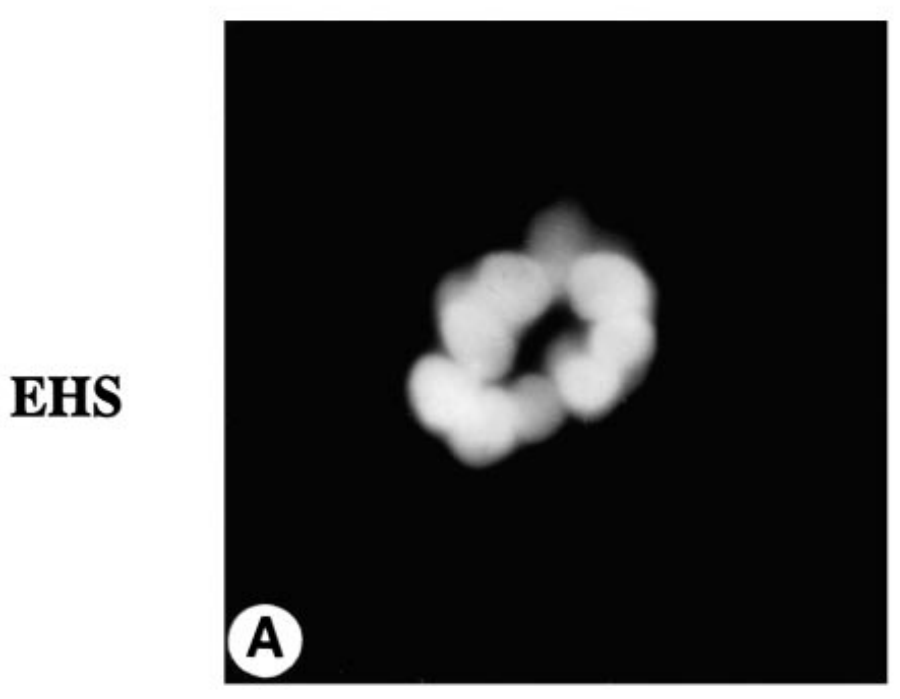

CI
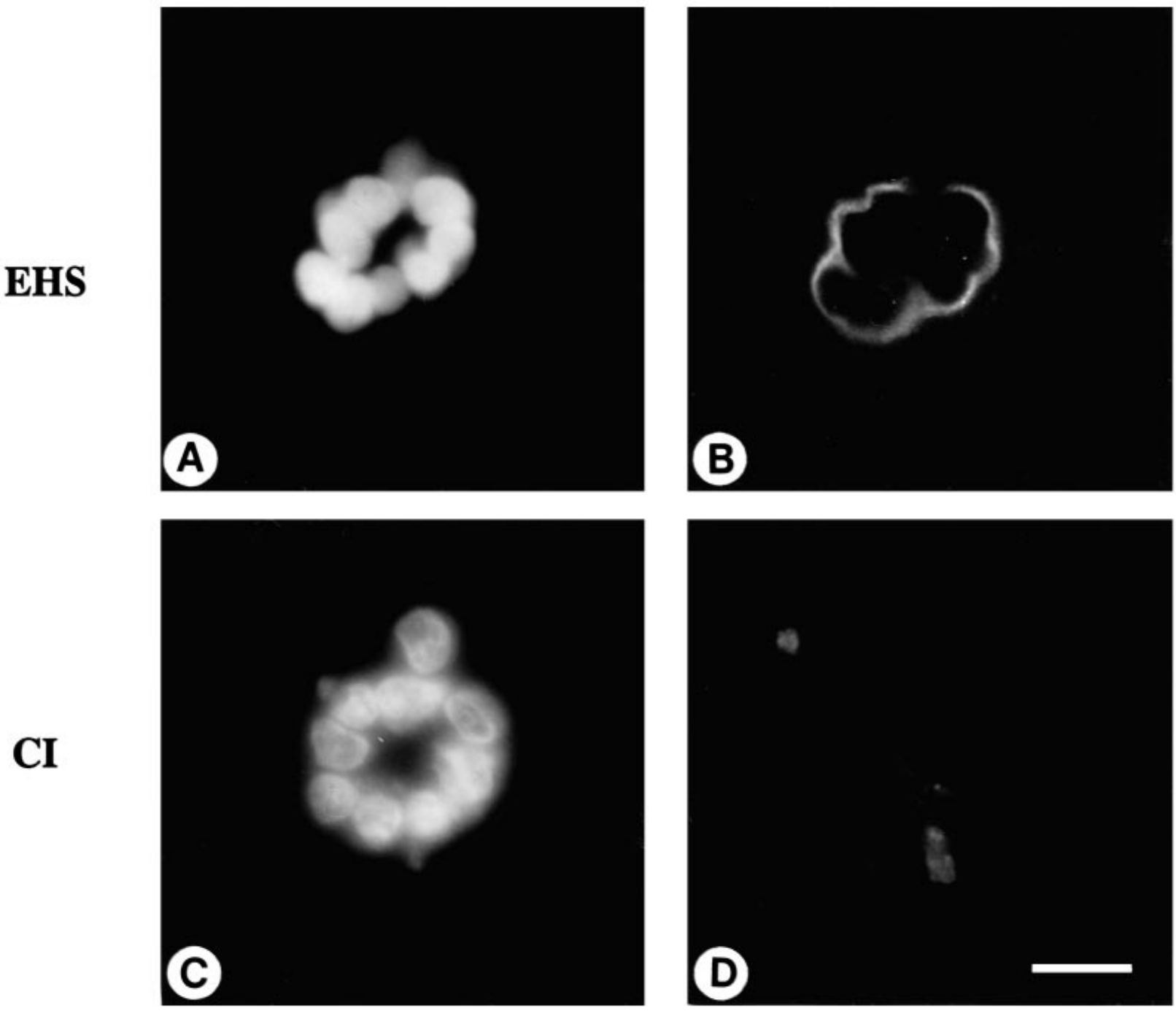

Expression of endogenous basement membrane by normal HMT-3522 cells cultured within reconstituted basement membrane (EHS) and type 1 collagen (CI) gels. HMT-3522 cells were cultured within 3- dimensional substrata for 12 days. $5 \mu \mathrm{m}$ frozen sections were double stained with DAPI to visualize nuclei (A,C) and with antibodies specific for human type IV collagen (CIV; B,D) to assess endogenous basement membrane immunoreactivity. Note that HMT-3522 cells form acinar structures in both substrata but basally deposit endogenous basement membrane in reconstituted BM only (B). Bar, $18 \mu \mathrm{m}$. 
TABLE 3

Table 3. Effect of function-blocking anti- $\beta 1$ integrin antibodies on normal breast epithelial cell growth within three-dimensional substrata

\begin{tabular}{lcc}
\hline & \multicolumn{2}{c}{ Thymidine-labeling index } \\
\cline { 2 - 3 } Substratum & $\begin{array}{c}\text { Medium } \\
\text { (no antibodies) }\end{array}$ & $\begin{array}{c}\text { Anti- } \beta 1 \\
\text { integrin }\end{array}$ \\
\hline Day 2 & $60 \pm 22$ & $2.2 \pm 5.7$ \\
EHS matrix & $62 \pm 23$ & $14.2 \pm 16$ \\
Collagen I & & \\
Day 6 & $3 \pm 3.5$ & $2.5 \pm 7$ \\
EHS matrix & $8.8 \pm 2.5$ & 0 \\
Collagen I & & \\
& &
\end{tabular}


TABLE 4

Table 4. Effect of function-blocking ant- $\beta 1$ integrin antibodies on colony formation and cellular growth of mammary carcinoma cells within reconstituted basement membrane

\begin{tabular}{lccccc}
\hline & \multicolumn{2}{c}{ Percentage of colonies* } & & \multicolumn{2}{c}{ Thymidine-labeling index $\dagger$} \\
\cline { 2 - 3 } \cline { 5 - 6 } Cells & $\begin{array}{c}\text { Non-immune } \\
\text { IgG }\end{array}$ & $\begin{array}{c}\text { Anti- } \beta 1 \\
\text { integrin }\end{array}$ & & $\begin{array}{c}\text { Medium } \\
\text { (no antibodies) }\end{array}$ & $\begin{array}{c}\text { Anti- } \beta 1 \\
\text { integrin }\end{array}$ \\
\hline HMT-3909/S13 & 61 & 100 & & $10.1 \pm 12.8$ & $19.2 \pm 10.1$ \\
MDA-MB-435 & 88 & 127.4 & & $9.0 \pm 5.0$ & $7.0 \pm 1.4$ \\
MCF-7/9 & ND & ND & & $25.0 \pm 8.6$ & $43.4 \pm 5.9$
\end{tabular}

*To assess colony formation, carcinoma cells were cultured in EHS matrix for a minimum of 6 days. The number of tumor colonies was scored microscopically in 10 random low-power fields. Colony frequency is expressed as a percentage relative to control cultures (no antibodies).

$\dagger$ To assess growth, carcinoma cells were cultured within Matrigel for 6 days. Cultures were labeled with $\left[{ }^{3} \mathrm{H}\right]$ thymidine and $5 \mu \mathrm{m}$ frozen sections were processed for autoradiography. Values are means \pm s.d.

The inhibitory anti- $\beta 1$ (AIIB2) integrin subunit antibody was used at 100 $\mu \mathrm{g} / \mathrm{ml}$. ND, not determined. 
FIGURE 4

Day 2

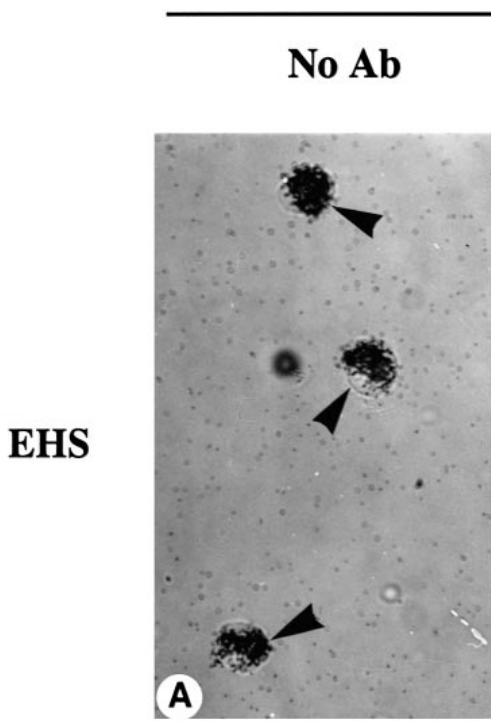

C I

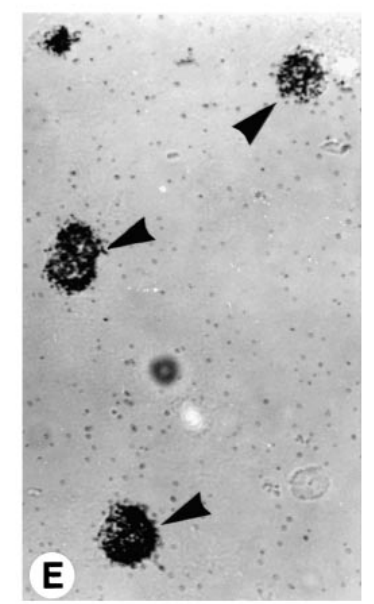

Anti- $\beta 1$
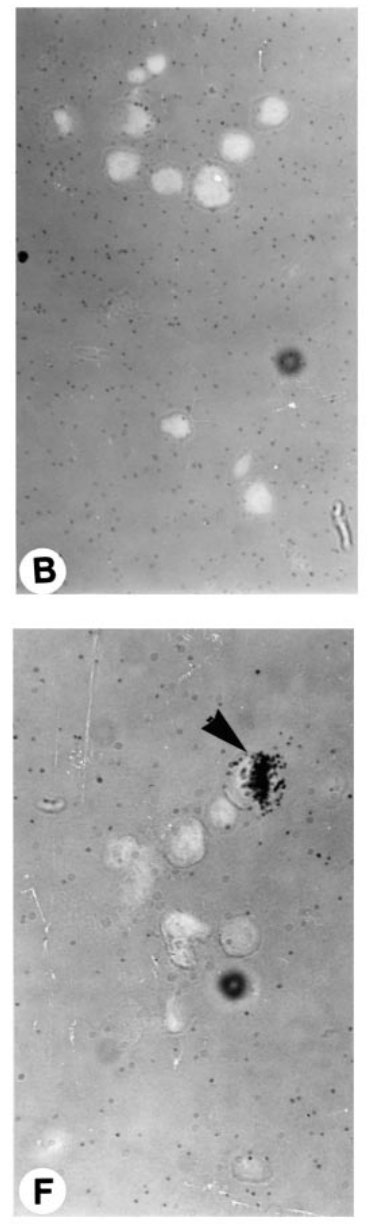

Day 6

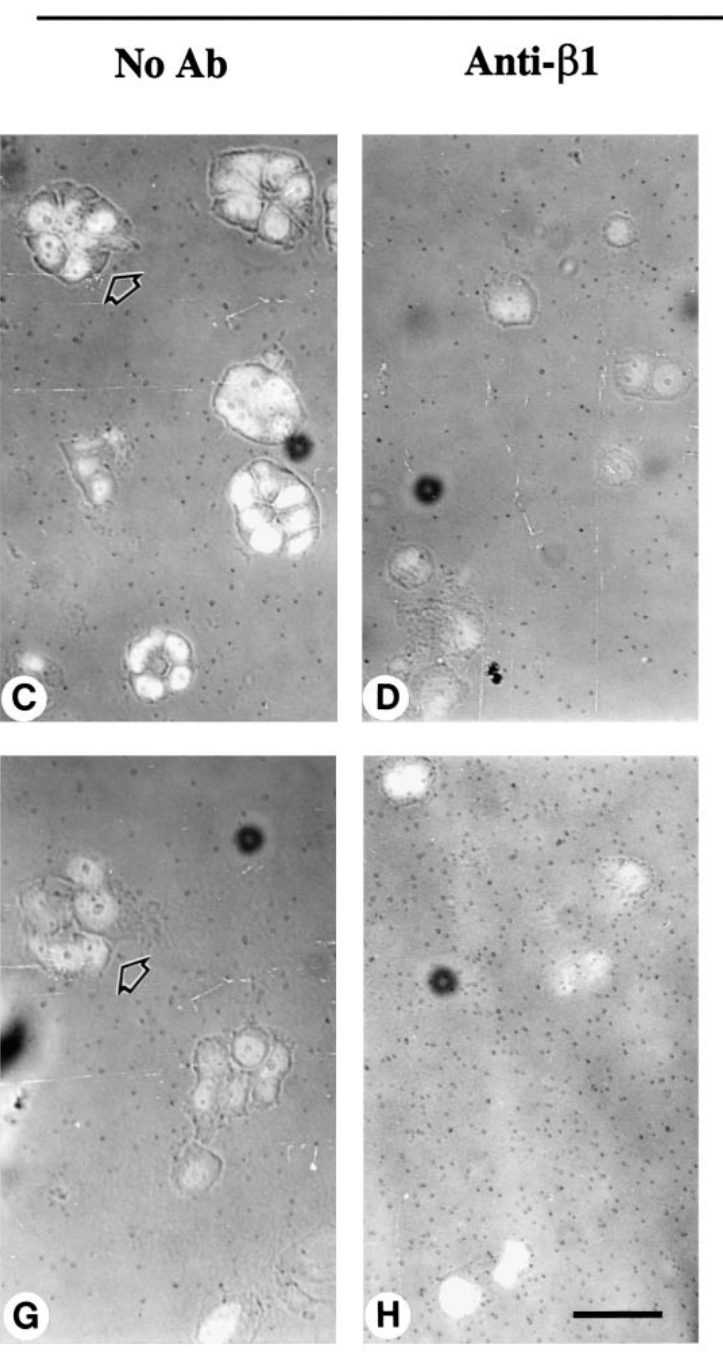

Inhibition of cellular growth within ECM substrata by function-blocking anti-integrin antibodies. Normal HMT-3522 cells were cultured within EHS matrix (EHS; A-D) and collagen I (CI; E-H) for 2-6 days. Cultures were labeled with [3H]thymidine on day 2 and day 6 of culture. $5 \mu \mathrm{m}$ frozen sections were stained with DAPI to visualize nuclei and processed for autoradiography. At day 2 a high proportion of nuclei are labeled with thymidine (arrowheads) in both ECM substrata in the absence of inhibitory anti-integrin antibodies (A,E). In contrast, few nuclei are labeled at day 2 in the presence of $100 \mu \mathrm{g} / \mathrm{ml}$ inhibitory anti- $\beta 1$ antibody (clone AIIB2) (B,F). By day 6 HMT-3522 cells cultured without antibodies proceed to form growth-arrested acinar structures in both ECM substrata (C,G) (open arrows), whereas in the presence of inhibitory anti$\beta 1$ antibodies the cells do not incorporate thymidine and fail to form acinar structures $(\mathrm{D}, \mathrm{H})$. Bar, $33 \mu \mathrm{m}$. 
FIGURE 5

No $\mathbf{A b}$
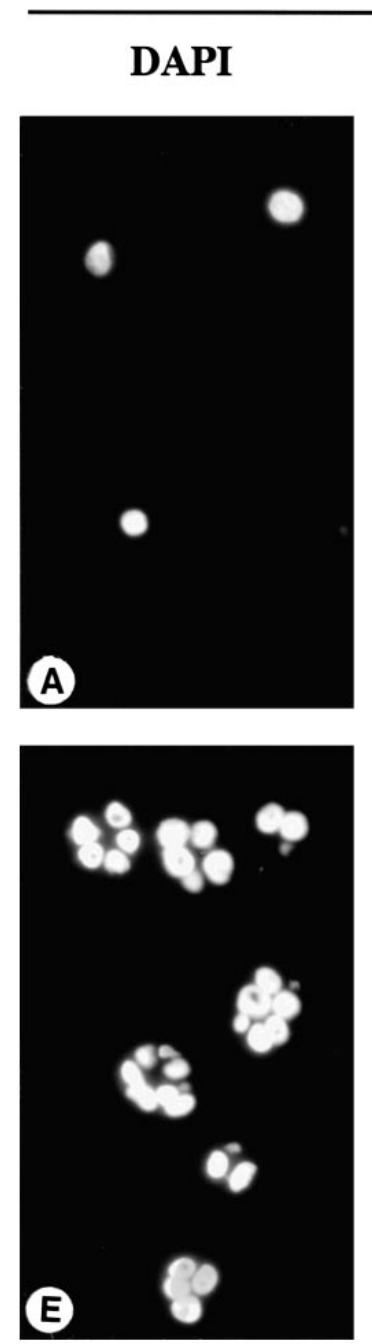

B

ApopTag
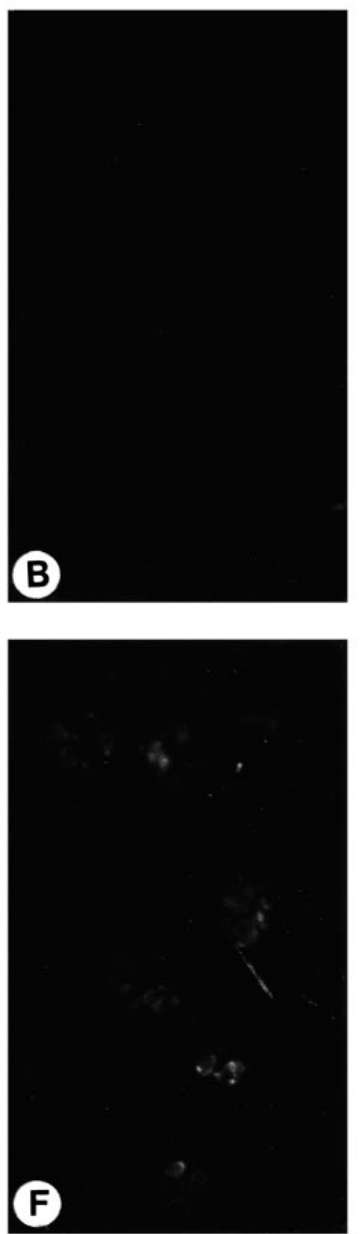

Anti-B1
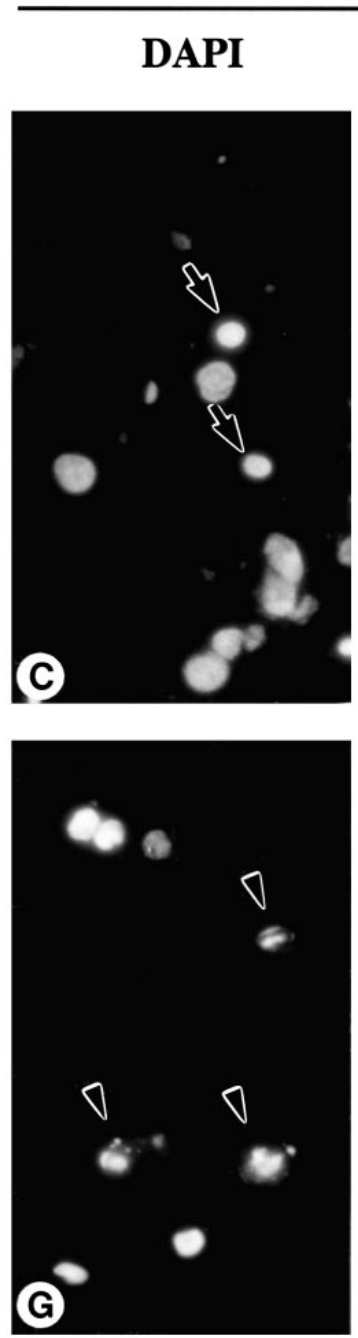

ApopTag
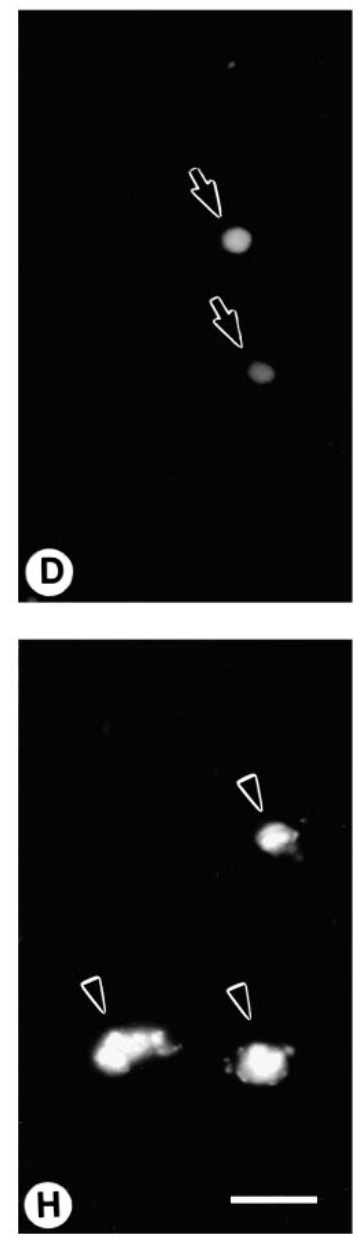

Induction of apoptosis within EHS matrix by function-blocking anti-integrin antibodies. Normal HMT-3522 cells were cultured within EHS matrix for 2-6 days. $5 \mu \mathrm{m}$ frozen sections were double-stained with DAPI to visualize nuclei (A,C,E,G) and with FITC-conjugated antidigoxigenin to detect digoxigenin-labeled genomic DNA in apoptotic nuclei (B,D,F,H). (AD) 2-day cultures of HMT-3522 cells suspended in EHS matrix without antibodies (A,B) or with $100 \mu \mathrm{g} / \mathrm{ml}$ inhibitory anti- $\beta 1$ integrin antibodies (clone AIIB2) (C,D). (E-H) 6-day cultures of HMT-3522 cells without antibodies (E,F) or with inhibitory anti- $\beta 1$ integrin antibodies $(\mathrm{G}, \mathrm{H})$. Note the presence of apoptotic nuclei (arrowheads) in cells which remain suspended as single cells after 6 days of culture with anti- $\beta 1$ integrin antibodies (H). Bar, $25 \mu \mathrm{m}$. 
FIGURE 6

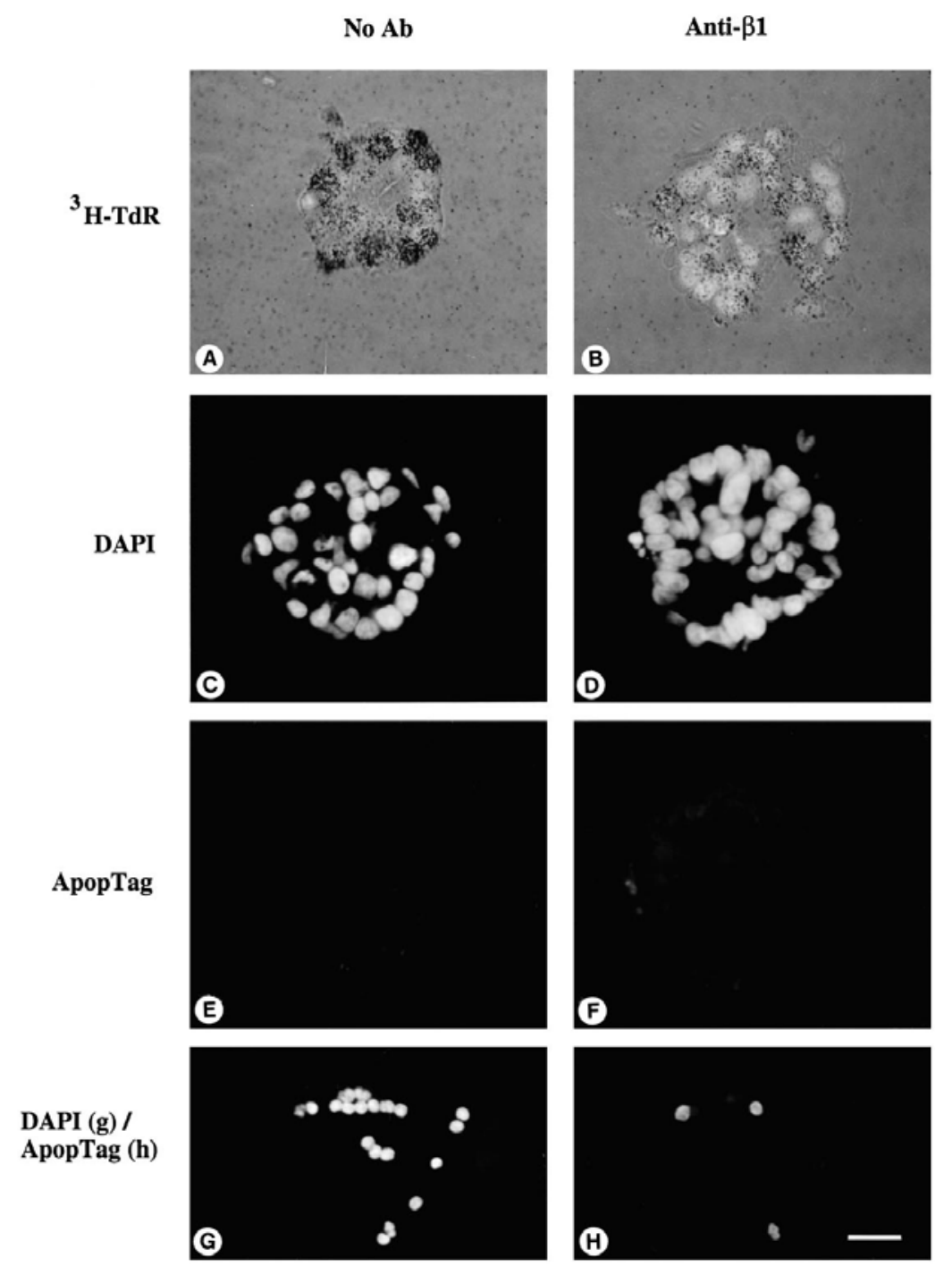

Effect of inhibitory anti-integrin antibodies on tumor colony formation, cellular growth and cell survival. MCF-7/9 cells were cultured for 6 days in reconstituted BM with no antibodies (A,C,E,) or with $100 \mu \mathrm{g} / \mathrm{ml}$ inhibitory anti- $\beta 1$ integrin antibodies (clone AIIB2) (B,D,F). Cultures were labeled with [3H]thymidine and $5 \mu \mathrm{m}$ frozen sections were stained with DAPI to visualize nuclei and then either processed for autoradiography $(A, B)$ or stained with FITCconjugated anti-digoxigenin to detect digoxigenin-labeled genomic DNA in apoptotic nuclei (B,D,F). (A,C,E) Colonies formed by MCF-7/9 cells cultured without antibodies that have thymidine-labeled nuclei (A) but no apoptotic nuclei (C, DAPI; E, FITC-antidigoxygenin). $(\mathrm{B}, \mathrm{D}, \mathrm{F})$ Similar colony formation by MCF-7/9 cells cultured with anti- $\beta 1$ integrin. The colonies also have thymidinelabeled nuclei (B) but no apoptotic nuclei (D, DAPI; F, FITC antidigoxygenin). (G,H) Control human peripheral blood leukocytes stained with DAPI $(\mathrm{G})$ and FITC-anti-digoxygenin $(\mathrm{H})$. Note the presence of apoptotic nuclei in the leukocytes $(\mathrm{H})$. Bar, 25 $\mu \mathrm{m}$. 